\title{
Formulation and Characterization of Nanoemulsion of Tread leave Ethanol Extract (Catharanthus roseus $($ L.) G. Don) as Antihyperglycemic
}

\author{
Mariadi $^{1,2 *}$, Bayu Eko Prasetyo ${ }^{1,2}$, Hanny Adela ${ }^{3}$, Winda Wiladatika ${ }^{3}$ \\ ${ }^{1}$ Department of Pharmaceutical Technology, Faculty of Pharmacy, Universitas Sumatera Utara, Medan, \\ 20155, Indonesia \\ ${ }^{2}$ Nanomedicine Center of Innovation, Universitas Sumatera Utara, Medan, 20155, Indonesia \\ ${ }^{3}$ University Tjut Nyak Dhien, Medan, Indonesia
}

\begin{abstract}
Nanoemulsion technology has been widely developed and applied on natural extract to enhance bioavailability and drug effects. The tread plant (Catharanthus roseus (L.) G. Don) is commonly known in traditional medicine for lowering blood sugar levels. This study aimed to make and characterize nanoemulsion of tread leaf extract as antihyperglycemic using sesame oil and olive oil as carriers. Nanoemulsion formulations were made using ethanol extract of tread leaves, and additives such as Tween 80, isopropyl myristate in varying ratios and some of vegetable oils. The physical test of nanoemulsion was evaluated including the $\mathrm{pH}$, the type of emulsion, homogeneity and size distribution which measured by the Particle Size Analyzer (PSA). Antihyperglycemic test was carried out on 4 groups of male mice ( 5 mice/ group) induced with glucose and treated with extract, nanoemulsion, and distilled water. The results showed that the nanoemulsion preparation had a $\mathrm{pH}$ of 6.4 to 6.5 ; o/w type of emulsion and it was stable on storage for 1 month. The particle size distribution of the nanoemulsion was $85.8 \%$ with size $<500 \mathrm{~nm}$. The antihyperglycemic test showed that this nanoemulsion could reduce the blood glucose levels in mice to normal level after 60 minutes and it is decreases from 43 to $46 \%$ after 2 hours. The Nanoemulsion of tread leaf extract has a faster ability and a greater percentage in reducing blood glucose levels compared to extract and control.
\end{abstract}

Keywords: Nanoemulsion, Catharanthus roseus, sesame oil, olive oil, Antihyperglikemic

\begin{abstract}
Abstrak. Teknologi nanoemulsi sudah banyak dikembangkan dan diaplikasikan pada ekstrak bahan alam untuk meningkatkan bioavaibilitas dan efek obat. Tanaman tapak dara (Catharanthus roseus (L.) G. Don) umumnya dikenal dalam pengobatan tradisional untuk menurunkan kadar gula darah. Penelitian ini bertujuan untuk membuat dan karakterisasi sediaan nanoemulsi ekstrak daun tapak dara sebagai antihiperglikemia menggunakan minyak wijen dan zaitun sebagai pembawa. Formulasi nanoemulsi dibuat menggunakan ekstrak etanol daun tapak dara, dan bahan tambahan seperti tween 80, isopropyl miristat dalam rasio yang bervariasi dan minyak nabati yang berbeda. Sediaan nanoemulsi dilakukan uji fisik meliputi pH sediaan, tipe emulsi, homogenitas dan distribusi ukurn yang diukur dengan alat Particle Size Analyzer (PSA). Pengujian antihiperglikemia sediaan dilakukan pada 4 kelompok mencit jantan (5 ekor/kelompok) yang diinduksi glukosa dan diberi perlakuan ekstrak, nanoemulsi ekstrak, dan akuades. Hasil menunjukkan bahwa sediaan nanoemulsi mempunyai pH 6,4-6,5; tipe m/a, dan stabil pada penyimpanan selama 1 bulan. Distribusi ukuran partikel sediaan mempunyai ukuran $<500$
\end{abstract}

\footnotetext{
*Corresponding author at: Department of Pharmaceutical Technology, Faculty of Pharmacy, Universitas

Sumatera Utara, Padang Bulan, Medan 20155, Indonesia

E-mail address: mariadi@usu.ac.id
} 
nm sebesar 85,8\%. Sediaan nanoemulsi dapat menurunkan kadar gula darah mencit menjadi normal pada menit ke-60 dengan persentase penurunan sebesar 43-46\% pada waktu 2 jam. Nanoemulsi ekstrak etanol daun tapak dara memiliki kemampuan lebih cepat dan persentase lebih besar dalam menurunkan kadar glukosa darah dibandingkan ekstrak dan kontrol.

Kata Kunci: Nano emulsi, Catharanthus roseus, Minyak Wijen, Minyak Zaitun, Anti Hiperglikemik

Received 5 December 2019 | Revised 18 December 2019 | Accepted 20 December 2019

\section{Introduction}

Indonesia has a variety of medicinal plants that have been used empirically and traditionally for orally usage in the community. But the traditional dosage form showed a low oral solubility and bioavailability, and it is required a substantial doses in their use to achieve the therapeutic effectiveness.

The nanoemulsion form is the choice which is expected to increase the oral solubility and bioavailability of the extracts of natural compound. In nano size $(50-500 \mathrm{~nm})$, the active ingredient particles are more easily absorbed by the intestinal wall, thereby increasing its bioavailability [1], [2], [3].

Nanoemulsion extract has better solubility and higher bioavaibility compared to the extract form [4]. In addition, nanoemulsion has a greater surface area and free energy, so it can prevent creaming, flocculation, coalescence and sedimentation [5].

One of the medicinal plants commonly used empirically for treatment in society is the leaves of the tread (Catharantus roseus) which is known to contain alkaloid compounds. The research on the activity of the tread plant as an anti-hyperglycemia has been carried out, such as the ethanol extract activity of tread leaves can reduce blood sugar levels in male white rats [6], infusion of tread leaves in the concentration range of $25-65 \%$ reduced blood glucose levels in white rats [7], and the combination effect of shredded leaf extract (Strobilanthes crispa (L.) Blume) and the tread leaves against anti-hyperglycemia of male Swiss Webster mice [8].

\section{Materials and Methods}

The materials used in this study were male mice (Mus musculus) (as the experimental animals), tread leaves (Catharanthus roseus (L.) G. Don) taken purposively from Simalingkar B, Medan and the determination process for plant identification carried out in Medanense Herbarium (MEDA ), Department of Biology FMIPA USU, Medan, with the authentication number 2112/ MEDA/ 2018. The Sesame oil, olive oil, Tween 80, Isopropyl Miristat, Aquades, Glucose, and Carboxyl Methyl Cellulose (CMC). 


\subsection{The Preparation of Tread Leaves Extract Nanoemulsion}

Nanoemulsion formulation was carried out by modification of the method of Saputra [9]. Nanoemulsion preparations were made according to the formula design as in Table 1.

Table 1. Nanoemulsion formulation of tread leave ethanol extract

\begin{tabular}{cccccc}
\hline \multirow{2}{*}{ Formula } & \multicolumn{5}{c}{ Ratio } \\
\cline { 2 - 6 } & $\begin{array}{c}\text { Tread leave ethanol } \\
\text { extract }\end{array}$ & $\begin{array}{c}\text { Sesame } \\
\text { oil }\end{array}$ & Olive oil & Tween 80 & $\begin{array}{c}\text { Isopropyl } \\
\text { miristat }\end{array}$ \\
\cline { 2 - 6 } F1 & 1 & 1.25 & - & 6 & 1.5 \\
F2 & 1 & - & 1.25 & 6 & 1.5 \\
\hline
\end{tabular}

Nanoemulsion preparations were made by mixing the ethanol extract of virgin tread leaves into vegetable oil until homogeneous and adding isopropyl myristate, stirring homogeneously (mass one). Tween 80 was dissolved in water, and then one mass was added, then stirred using a hot plate magnetic stirrer at $70^{\circ} \mathrm{C}$ for 6 hours and followed by 1 hour sonication process.

\subsection{Characterization of Nanoemulsion Preparations}

\subsubsection{Physical Characterization of Nanoemulsion}

The $\mathrm{pH}$ determination of the nanoemulsion was conducted using a $\mathrm{pH}$ meter, determination of emulsion type by using a methylene blue, and the stability test of nanoemulsion preparation is done visually on changes in color, odor, shape, and taste at room temperature for 1 month.

\subsubsection{Particle Size Distribution of Nanoemulsion}

The determination of particle size distribution for the nanoemulsion was done using the Particle Size Analyzer (Fritsch Analysettee 22 NanoTec).

\subsubsection{The Effect of Nanoemulsions on Decreasing Blood Glucose Levels}

Antihyperglycemic test was carried out on animal experiments using 20 mice which were divided into 4 groups (5 mice/ group). The treatment plan for each group is as in Table 2.

Table 2. Treatment plans for the antihyperglycemic test

\begin{tabular}{|c|c|c|c|}
\hline No & Group & Treatment & Formula \\
\hline 1 & I & Control (Distilled water) & - \\
\hline 2 & II & $\begin{array}{c}\text { Tread leave extract suspended in } \\
\text { CMC suspension }\end{array}$ & - \\
\hline 3 & III & $\begin{array}{c}\text { Nanoemulsion of tread leaves } \\
\text { extract }\end{array}$ & F1 \\
\hline 4 & IV & $\begin{array}{c}\text { Nanoemulsion of tread leaves } \\
\text { extract }\end{array}$ & $\mathrm{F} 2$ \\
\hline
\end{tabular}

Before the experiment, each group of mice was weighed and measured the blood sugar levels as initial blood sugar levels. The mice were fasted for 8 hours (not fed) before the experiment, and then every mouse was measured fasting blood sugar levels. Each group was induced 30\% 
glucose solution orally $(9.75 \mathrm{mg} / \mathrm{Kg} \mathrm{BW}$, conversion of mice dose $=0.0026)$, after 30 minutes, the blood sugar levels of mice were measured, the nanoemulsion and extract were treated, then every 15 minutes blood glucose levels were measured up to two hours

\section{Result and Discussion}

\subsection{Nanoemulsion Preparations}

Nanoemulsion extract of ethanol tread leaves has a blackish green color, slightly viscous, and has a distinctive odor.

\subsection{The pH of Nanoemulsion}

The $\mathrm{pH}$ test of nanoemulsion extracts of tread leaves was carried out using a $\mathrm{pH}$ meter. Nanoemulsion preparations have a $\mathrm{pH}$ in the range of 6.2-6.6 as shown in Table 3.

Table 3. $\mathrm{pH}$ value of tread leave ethanol extract nanoemulsion

\begin{tabular}{ccc}
\hline \multirow{2}{*}{$\begin{array}{c}\text { Time } \\
\text { (week) }\end{array}$} & F1 & pH \\
\cline { 2 - 3 } & 6.4 & 6.6 \\
1 & 6.4 & 6.5 \\
2 & 6.4 & 6.5 \\
3 & 6.2 & 6.4 \\
4 & 6.2 & 6.3 \\
\hline
\end{tabular}

From the table 3 it can be seen that there was a very good stability of the $\mathrm{pH}$ value for all of the formulations during storage in room temperature, the $\mathrm{pH}$ showed a constant value, it was only showed a slight decrease $\mathrm{pH}$, but it was still relatively stable.

\subsection{Type of Emulsion}

The type of emulsion is determined by the addition of methylene blue. The test showed that methylene blue was evenly dispersed in the nanoemulsion. It concluded that the nanoemulsion type is oil in water $(\mathrm{o} / \mathrm{w})$.

\subsection{Size Distribution of Nanoemulsion}

The results of the analysis of the nanoemulsion size distribution of the ethanol extract of tread leaves can be seen in Table 4 . 
Table 4. The percentages of particle size distribution

\begin{tabular}{llll}
\hline \multirow{2}{*}{ Formula } & \multicolumn{3}{l}{ The percentages of particle size distribution } \\
\cline { 2 - 4 } & $\mathbf{0 - 5 0 0} \mathbf{~ n m}$ & $\mathbf{5 0 0}-\mathbf{1 0 0 0} \mathbf{~ n m}$ & $\mathbf{2 1 0 0 0} \mathbf{~ n m}$ \\
\hline F1 & $97.2 \%$ & $0 \%$ & $2.8 \%$ \\
F2 & $85.8 \%$ & $0 \%$ & $14.2 \%$ \\
\hline
\end{tabular}

From Table 4, it can be known that the difference in size and percentage of particle size distribution of nanoemulsion preparations with different carrier oils. The formula 1 (with sesame oil) gives a smaller, homogeneous globule size and percentage of nanoemulsion size distribution was $97.2 \%$ below $<500 \mathrm{~nm}$, while the formula 2 (with olive oil) has $85.8 \%$ globul size $<500 \mathrm{~nm}$, and it has $14.2 \%$ globule size $>1000 \mathrm{~nm}$.

\subsection{Stability of Nanoemulsion Preparations}

The stability of the nanoemulsion preparation was carried out during 4 weeks storage, at room temperature and observed the changes in color, odor, shape, $\mathrm{pH}$ and phase separation. Nanoemulsion stability results shows that nanoemulsion has color and odor that does not change, $\mathrm{pH}$ is relatively stable and there is no phase separation from the beginning of manufacture until the 4 th week.

\subsection{Effects of Preparations on Reducing Blood Glucose Levels}

The effect of nanoemulsion containing extract compared with the extract suspended in sodium $\mathrm{CMC}$ on reducing blood glucose levels after treatment can be seen in Table 5 and the percentage of blood glucose decrease can be described in Figure 1.

Table 5. The influence of treatment on reducing blood glucose levels

\begin{tabular}{|c|c|c|c|c|c|c|c|c|c|c|c|}
\hline \multirow[b]{2}{*}{ Group } & \multicolumn{10}{|c|}{ Mean value of reducing blood glucose level (mg/dL) } & \multirow[b]{2}{*}{$120^{\prime}$} \\
\hline & Basal & $\begin{array}{l}\text { Fasting } \\
\text { glucose }\end{array}$ & $\begin{array}{l}\text { Glucose } \\
\text { nduction }\end{array}$ & 15 & 30' & 45 & 60' & $75^{\prime}$ & 90 & $105^{\prime}$ & \\
\hline \multirow{2}{*}{$\mathbf{I}$} & 129.6 & 78.8 & 180.4 & 177.2 & 176.2 & 175.6 & 172.6 & 161.4 & $\begin{array}{l}151 . \\
8\end{array}$ & $\begin{array}{l}143 . \\
8\end{array}$ & 136.4 \\
\hline & \pm 2.3 & \pm 12.1 & \pm 10.3 & \pm 8.8 & \pm 9.1 & \pm 7.1 & \pm 9.9 & \pm 15.9 & $\begin{array}{l} \pm 16 . \\
3\end{array}$ & $\begin{array}{l} \pm 17 . \\
1\end{array}$ & \pm 13.2 \\
\hline \multirow[t]{2}{*}{ II } & 131.6 & 81.8 & 178.8 & 178.6 & 168.0 & 153.8 & 121.0 & 120.4 & $\begin{array}{l}119 . \\
4\end{array}$ & $\begin{array}{l}116 . \\
0\end{array}$ & 105.0 \\
\hline & \pm 2.4 & \pm 9.5 & \pm 7.6 & \pm 7.7 & \pm 8.3 & \pm 14.6 & \pm 3.5 & \pm 3.5 & \pm 3.7 & \pm 2.1 & \pm 10.8 \\
\hline \multirow{2}{*}{ III } & 129.6 & 78.8 & 179.6 & 164.4 & 147.4 & 127.6 & 116.8 & 113.2 & $\begin{array}{l}108 . \\
0\end{array}$ & $\begin{array}{l}102 . \\
2\end{array}$ & 97 \\
\hline & \pm 2.3 & \pm 12.0 & \pm 9.5 & \pm 25.2 & \pm 20.1 & \pm 16.4 & \pm 12.6 & \pm 10.8 & \pm 7.1 & \pm 3.5 & \pm 4.8 \\
\hline \multirow[t]{2}{*}{ IV } & 129.6 & 78.8 & 179.6 & 175.6 & 152.4 & 120.4 & 117.6 & 114.4 & $\begin{array}{l}110 . \\
2\end{array}$ & $\begin{array}{l}105 . \\
2\end{array}$ & 101.0 \\
\hline & \pm 2.3 & \pm 12.1 & \pm 9.5 & \pm 7.3 & \pm 4.8 & \pm 3.2 & \pm 3.9 & \pm 3.3 & \pm 6.5 & \pm 6.7 & \pm 5.1 \\
\hline
\end{tabular}




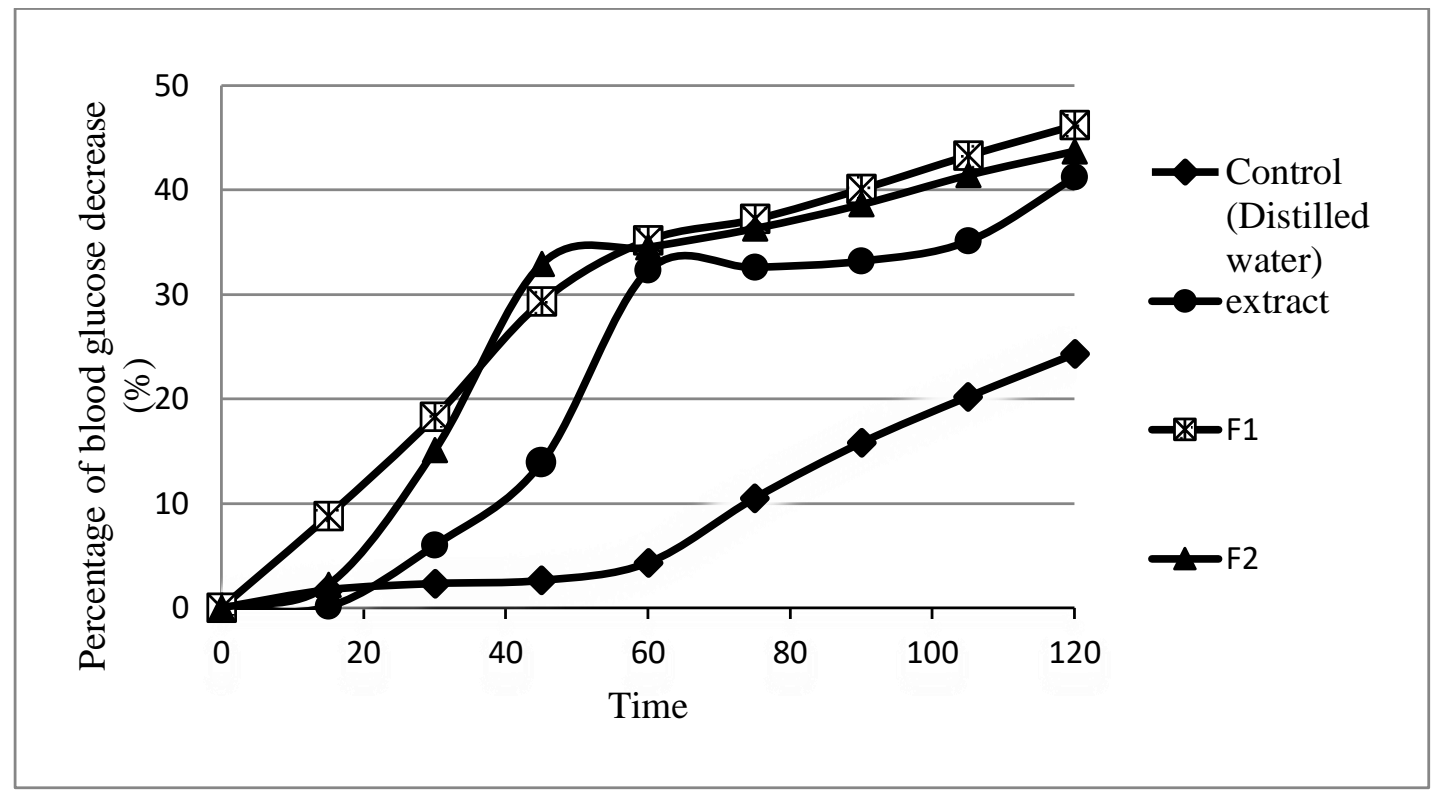

Figure 1. The effect of nanoemulsion in percentage of blood glucose decrease in mice

From the data it can be stated that the decrease profile of blood glucose levels in mice that have been induced and treated, in groups III and IV which is given nanoemulsion extract treatment (F1 and F2) showed an influence on decreasing blood glucose levels that are greater and faster than group I and II were given extract and control preparations (distilled water). In groups III and IV, the normal blood glucose levels can be achieved in the 60 minute with blood glucose levels less than $120 \mathrm{mg} / \mathrm{dL}$ (normal blood sugar levels in mice is $71 \mathrm{mg} / \mathrm{dL}-124 \mathrm{mg} / \mathrm{dL}$ ).

The percentage reduction in blood glucose levels in groups III and IV that treated with nanoemulsion preparations (F1 and F2) at 2 hours was also greater than in groups I and II, which amounted to $43-46 \%$. It can be understood that the dosage particle size affects the absorption of the drug. The smaller particle size will facilitate penetration through capillaries, so the availability of drugs in the target cell is more maximal. The emulsion preparation with nano size (nanoemulsion) also can increase absorption, and the bioavailability of the drug [2], [10].

\section{Conclusion}

From the results it can be concluded that tread leaf extract can be formulated as a nanoemulsion preparation with a stable carrier of olive oil and sesame oil for 1 month. Nanoemulsion preparations of tread leaf extract showed the ability to reduce blood sugar levels in mice faster and the percentage reduction in blood sugar levels was greater than the ethanol extract of the tread leaf suspended with sodium CMC and control. 


\section{REFERENCES}

[1] O. Kammona and C. Kiparissides, "Recent advances in nanocarrier-based mucosal delivery of biomolecules.," J. Control. Release, vol. 161, no. 3, pp. 781-94, Aug. 2012.

[2] N. Poulain and E. Nakache, "Nanoparticles from vesicles polymerization. II. Evaluation of their encapsulation capacity," J. Polym. Sci. Part A Polym. Chem., 1998.

[3] A. Gupta, H. B. Eral, T. A. Hatton, and P. S. Doyle, "Nanoemulsions: Formation, properties and applications," Soft Matter, vol. 12, no. 11. Royal Society of Chemistry, pp. 2826-2841, 2016.

[4] N. Jusnita and W. Syurya, "369-1167-5-PB,” J. Sains Farm. Klin., vol. 6, no. 1, pp. 1624, 2019.

[5] P. K. Gupta, J. K. Pandit, A. Kumar, P. Swaroop, and S. Gupta, "Pharmaceutical Nanotechnology Novel Nanoemulsion -High Energy Emulsification Preparation, Evaluation and Application the Pharma Research, a Journal," Ph. Res. Pharma Res. (T. Ph. Res.), vol. 3, no. 3, pp. 117-138, 2010.

[6] H. Soriton, P. V. Y. Yamlean, and W. A. Lolo, "Uji Efektivitas Ekstrak Etanol Daun Tapak Dara (Catharantus roseus (L.) G.Don) Terhadap Penurunan Kadar Gula Darah Tikus Putih Jantan Galur Wistar (Rattus norvegicus L.) Yang Diinduksi Sukrosa," PHARMACON J. Ilm. Farm., vol. 3, no. 3, pp. 162-169, 2014.

[7] Y. Permatasari, L. Febrina, and A. Ibrahim, "Prosiding Seminar Nasional Kefarmasian Ke-2, Samarinda," in Aktivitas Infusa Daun Tapak Dara (Catharanthus roseus L.) Terhadap Penurunan Kadar Glukosa Darah Tikus Putih (Rattus Norvegicus), 2015, pp. $62-66$.

[8] U. I. B. Yuniarni, N. Amanah, and S. Hazar, "Prosiding KNMSA 2015," in Aktivitas Antihiperglikemik Ekstrak Etanol Daun Keji Beling dan Tapak Dara serta Kombinasinya pada Mencit Swiss Webster Jantan yang Diinduksi Aloksan, 2015, pp. 345-349.

[9] F. R. Ningrum, U. I. Indonesia, A. D. Saputra, and U. I. Indonesia, "Formulasi Nanoemulsi Daun Pisang dengan Zat Epigallochatecin Gallate sebagai Zat Anti Kanker," no. April, pp. 0-7, 2017.

[10] S. Huang and W. Chang, "Advantages of Nanotechnology- Based Chinese Herb Drugs on Biological Activities," Curr. Drug Metab., vol. 10, no. 8, pp. 905-913, Oct. 2009. 